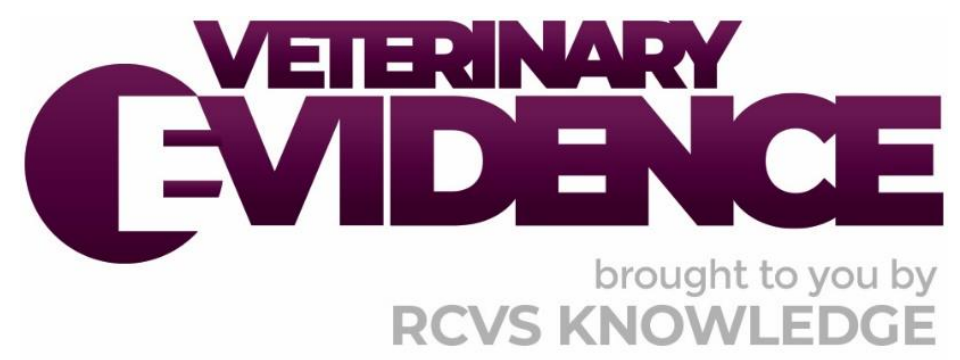

\title{
There is no superior treatment method for medial shoulder instability in dogs
}

\section{A Knowledge Summary by}

Nina R. Kieves DVM, DACVS-SA, DACVSMR ${ }^{1^{*}}$

Stephen C. Jones MVB, MS, DACVS-SA ${ }^{1}$

\footnotetext{
${ }^{1}$ The Ohio State University, Columbus, OH 43210, United States

*Corresponding Author (nkieves@gmail.com)
}

ISSN: 2396-9776

Published: 20 Feb 2020

in: Vol 5, Issue 1

DOI: $10.18849 / \mathrm{VE} . \mathrm{V} 511.249$

Reviewed by: Sherman O. Canapp (DVM, MS, CCRT) and Samuel P. Franklin (MS, DVM, PhD)

Next Review Date: Jun 22nd 2020 


\section{KNOWLEDGE SUMMARY}

\section{PICO question}

In dogs with medial shoulder instability, what treatment option results in the best patient outcomes medical vs. surgical management?

\section{Clinical bottom line}

\section{Category of research question}

Treatment

\section{The number and type of study designs reviewed}

10 papers were critically reviewed. Whilst one study was prospective in nature, it was performed in research dogs that were then euthanised to evaluate outcome of various surgical procedures. Of the remaining nine papers reviewed, six were retrospective studies, two were case reports, and one was a combination of a cadaveric project with case report

\section{Strength of evidence}

Weak

\section{Outcomes reported}

Surgical and medical treatment of medial shoulder instability can be successful. There is no strong evidence to support one surgical treatment over another

\section{Conclusion}

Dogs diagnosed with medial shoulder instability may be treated successfully with either medical or surgical management

\section{How to apply this evidence in practice}

The application of evidence into practice should take into account multiple factors, not limited to: individual clinical expertise, patient's circumstances and owners' values, country, location or clinic where you work, the individual case in front of you, the availability of therapies and resources.

Knowledge Summaries are a resource to help reinforce or inform decision making. They do not override the responsibility or judgement of the practitioner to do what is best for the animal in their care.

\section{Clinical Scenario}

A 4-year-old border collie who participates in agility, is presented to you for poor performance and consistently missing weave polls. You find pain with manipulation of the shoulder joint and suspect medial shoulder instability. How do you best treat this patient?

\section{The evidence}

Ten studies were reviewed in this knowledge summary. None were clinical prospective studies, and most had very small case numbers, or were case reports. To date, no prospective randomised trial has been performed to evaluate the effects of medical management of medial shoulder instability (MSI) compared to any surgical technique. Nor, have there been any prospective evaluations comparing the various surgical techniques reported. MSI can encompass damage to only the medial glenohumeral ligament (MGL), only the subscapularis muscle/tendon, or a combination of both as well as the joint capsule. This poses a challenge when evaluating the best options for treatment of MSI as medical management may be most appropriate for one type of instability, while another may require surgical intervention. This plays a role in the evaluation of the ideal 
surgical treatment as well. Often times, this information is not fully reported and all cases are treated the same; some reports may even include traumatic and congenital luxation with MSI cases for treatment and outcome evaluation.

No systematic reviews or meta-analysis have been performed on this topic, for either medical management of MSI, or surgical treatment. There are also no randomised studies evaluating various treatments. Most evidence comprised of single or low number case reports or case studies, with Franklin et al. (2013) having the most robust retrospective evaluation of cases.

\section{Summary of the evidence}

\begin{tabular}{|c|c|}
\hline \multicolumn{2}{|l|}{ Becker et al. (2015) } \\
\hline Population: & Canine \\
\hline Sample size: & $\begin{array}{l}\text { - } 28 \text { dogs with shoulder related lameness initially identified, } \\
15 / 28 \text { dogs met the inclusion criteria and were included in } \\
\text { the study } \\
\text { - } 4 / 15 \text { included were diagnosed with medial shoulder } \\
\text { instability (MSI) and } 1 / 15 \text { was diagnosed with MSI and } \\
\text { supraspinatus tendinopathy } \\
\text { - The remaining } 13 / 28 \text { dogs had shoulder lameness secondary } \\
\text { to diagnoses not relevant to this PICO and will not be } \\
\text { commented on further }\end{array}$ \\
\hline Intervention details: & $\begin{array}{l}\text { - Dogs were treated with shockwave therapy } \\
\text { - Two dogs also on tramadol; one dog also on carprofen } \\
\text { - Specific doses were not given for shockwave treatment; of } \\
\text { all } 15 \text { dogs a mean number of impulses/treatment was } 1103 \\
\pm 340 \text { (range } 750-1500 \text { ) [sic] and mean energy level of } \\
\text { impulse delivered was } 0.24 \pm 0.03 \mathrm{~mJ} / \mathrm{mm}^{2} \text { (range } 0.21-0.26 \\
\mathrm{~mJ} / \mathrm{mm}^{2} \text { ) [sic] }\end{array}$ \\
\hline Study design: & Retrospective \\
\hline Outcome studied: & $\begin{array}{l}\text { - Retrospective evaluation of resolution of lameness } \\
\text { - Owner telephone questionnaire for long-term follow-up }\end{array}$ \\
\hline $\begin{array}{l}\text { Main findings: } \\
\text { (relevant to PICO question): }\end{array}$ & $\begin{array}{l}\text { - Of the five MSI dogs, one had improved angle of abduction } \\
\text { (this was not defined further); two were unavailable for } \\
\text { follow-up } \\
\text { Of the three available for follow-up ( } 3.25 \text { years, } 2.58 \text { years, } \\
0.5 \text { years) all were still lame; two were graded as being the } \\
\text { same and one was improved, but not normal }\end{array}$ \\
\hline Limitations: & $\begin{array}{l}\text { - No specific treatment protocol provided for MSI vs. other } \\
\text { - } \\
\text { - No objective gait evaluation was performed } \\
\text { - No validated owner outcome assessment was used } \\
\text { - No comparison to surgical treatments or other medical } \\
\text { - } \text { management } \\
\text { Long-term assessment via phone; majority of dogs not } \\
\text { available for questionnaire and not evaluated long-term }\end{array}$ \\
\hline
\end{tabular}




\begin{tabular}{|c|c|}
\hline \multicolumn{2}{|l|}{ Cook et al. (2005) } \\
\hline Population: & Canine \\
\hline Sample size: & $\begin{array}{l}\text { - } 43 \text { dogs ( } 28 \text { males, } 15 \text { females) of various breeds; age range } \\
2-8 \text { years } \\
\text { - } 19 / 43 \text { ( } 44 \% \text { ) right medial shoulder instability (MSI), 22/43 } \\
\text { (51\%) left } \mathrm{MSI} \text {, and 2/43 (5\%) bilateral MSI }\end{array}$ \\
\hline Intervention details: & $\begin{array}{l}\text { - All } 43 \text { dogs were treated arthroscopically with } \\
\text { radiofrequency induced thermal capsulorrhaphy (RITC) } \\
\text { - Initially a monopolar radiofrequency (RF) generator (Oratec } \\
\text { ORA-50 or Vulcan EAS, ORATEC, Menlo Park, CA) and mini } \\
\text { and micro TAC-S probes (ORATEC) was used set at } 40 \mathrm{~W} \text { and } \\
67^{\circ} \mathrm{C} \text {; for later cases a new generator and probe were used } \\
\text { with default settings of } 25 \mathrm{~W} \text { at } 70^{\circ} \mathrm{C} \\
\text { - In all cases a paint brush technique was used to apply the RF } \\
\text { probe through a caudal portal to the medial joint capsule, } \\
\text { medial glenohumeral ligament (MGL), and subscapularis } \\
\text { tendon } \\
\text { - This was repeated 3-4 times until visible shrinkage was } \\
\text { noted } \\
\text { All dogs were given the same postoperative care instructions }\end{array}$ \\
\hline Study design: & Retrospective \\
\hline Outcome studied: & $\begin{array}{l}\text { - Postoperative abduction angles were measured immediately } \\
\text { postoperatively, } 8 \text { weeks postoperatively, between 16-20 } \\
\text { weeks postoperatively, and approximately } 1 \text { year } \\
\text { postoperatively } \\
\text { - Outcome was graded as excellent, improved, or a failure }\end{array}$ \\
\hline $\begin{array}{l}\text { Main findings: } \\
\text { (relevant to PICO question): }\end{array}$ & $\begin{array}{l}\text { - } \quad \text { RITC was found to be safe } \\
\text { - Dogs had no significant difference in shoulder abduction } \\
\text { angles following RITC } \\
\text { - } 40 / 43 \text { ( } 93 \% \text { ) of dogs were considered improved at } 1 \text { year or } \\
\text { greater follow up; } 34 / 43 \text { ( } 79 \%) \text { were considered to have an } \\
\text { excellent outcome (time of this outcome is not reported i.e. } \\
1 \text { year or } 8 \text { week) } \\
\text { - } 3 / 43(7 \%) \text { were considered a failure; an explanation was } \\
\text { given for all of these cases }\end{array}$ \\
\hline Limitations: & $\begin{array}{l}\text { - As this was a live client owned study, no histopathology was } \\
\text { performed of the ligaments after treatment to evaluate } \\
\text { changes to the ligament } \\
\text { - Treatment protocol varied slightly with new probes being } \\
\text { used at some point during the study } \\
\text { - Shoulder abduction angle was a primary outcome } \\
\text { evaluation, which has recently been questioned as an } \\
\text { accurate evaluation of shoulder instability }\end{array}$ \\
\hline
\end{tabular}




\begin{tabular}{|l|l|}
\hline - No objective gait evaluation was performed \\
- No validated owner outcome assessment was used \\
- No comparison to other surgical treatments or medical \\
management \\
- Dogs were not differentiated in terms of degree of ligament \\
damage, nor how many ligaments were affected (i.e. MGL \\
alone vs. MGL with supraspinatus tendinopathy and/or joint \\
capsule) in regards to their outcome
\end{tabular}

Fitch et al. (2001)

\begin{tabular}{|c|c|}
\hline Population: & Canine \\
\hline Sample size: & $\begin{array}{l}\mathrm{n}=10 \text {; eight medial shoulder instability (MSI), one congenital } \\
\text { shoulder luxation, and one traumatic induced complete shoulder } \\
\text { luxation }\end{array}$ \\
\hline Intervention details: & $\begin{array}{l}\text { - All ten dogs in the report underwent surgery via } \\
\text { craniomedial approach to the shoulder, incision of } \\
\text { subscapularis and arthrotomy } \\
\text { - } \quad \text { Placement of medial glenohumeral ligament (MGHL) } \\
\text { prosthetic suture placed with fishing leader line } \\
\text { - Hole drilled just distal to insertion of MGHL and suture } \\
\text { anchor placed with fishing leader line; holes drilled at origins } \\
\text { of caudal and cranial component of MGHL - some cases had } \\
\text { suture anchors placed at both sites, later cases bone tunnels } \\
\text { were placed in the scapula replacing the suture anchors } \\
\text { - If suture anchors were used two independent loops were } \\
\text { tied for the cranial and caudal components } \\
\text { With bone tunnels the suture was placed from the humeral } \\
\text { suture anchor, looped through the caudal bone tunnel in the } \\
\text { scapula underneath the infraspinatus and supraspinatus } \\
\text { against the lateral surface of the scapula and then passed } \\
\text { through the cranial bone tunnel and tied } \\
\text { - Medial joint capsule was imbricated } \\
\text { Velpeau sling placed 2-4 weeks }\end{array}$ \\
\hline Study design: & Retrospective case series \\
\hline Outcome studied: & $\begin{array}{l}\text { Gait evaluation, standing, recumbent and sedated } \\
\text { orthopaedic examinations; shoulder drawer movement and } \\
\text { abduction angle measured } \\
\text { - Recheck at } 12 \text { weeks; phone interview, mail questionnaire, } \\
\text { radiographs and orthopaedic exam performed for long-term } \\
\text { evaluation }\end{array}$ \\
\hline $\begin{array}{l}\text { Main findings: } \\
\text { (relevant to PICO question): }\end{array}$ & $\begin{array}{l}\text { - } 7 / 8 \text { dogs with MSI good to excellent outcome following } \\
\text { surgery, with normal use of limb if evaluated (one dog lost to }\end{array}$ \\
\hline
\end{tabular}




\begin{tabular}{|l|l|l|}
\hline & $\begin{array}{l}\text { follow-up); one dog fair-good outcome and was still lame } 5 \\
\text { months postoperative, later diagnosed with osteosarcoma of } \\
\text { proximal humerus of affected limb }\end{array}$ \\
& $\begin{array}{l}\text { Three dogs with MSI discomfort on unoperated limb at } \\
\text { recheck }\end{array}$ \\
& $\begin{array}{l}\text { - } \\
\text { - }\end{array}$ \\
& Three dogs with MSI had stable implants with no progression \\
& of degenerative joint disease on radiographs \\
\hline Limitations: & $\begin{array}{l}\text { Retrospective study } \\
\text { - Not all dogs evaluated long-term }\end{array}$ \\
& - No objective measurements of abduction or joint range of \\
& motion performed; no objective gait analysis \\
\hline
\end{tabular}

Franklin et al. (2013)

\begin{tabular}{|c|c|}
\hline Population: & Canine \\
\hline Sample size: & $\begin{array}{l}\mathrm{n}=130 \text { dogs; } 101 \text { dogs (104 shoulders) with medial shoulder } \\
\text { instability (MSI), } 10 \text { dogs (10 shoulders) with lateral shoulder } \\
\text { instability (LSI), } 19 \text { dogs (19 shoulders) with multidirectional } \\
\text { instability (MDI) }\end{array}$ \\
\hline Intervention details: & $\begin{array}{l}\text { - Overall (MSI, LSI and MDI dogs), } 41 \% \text { ( } 53 \text { dogs) were treated } \\
\text { with medical management, } 7 \% \text { ( } 9 \text { dogs) with radiofrequency } \\
\text { induced thermal capsulorrhaphy (RITC), and 52\% (68 dogs) } \\
\text { with reconstruction } \\
\text { - For MSI specifically: } 48 \% \text { ( } 48 \text { dogs) medical management, } 9 \% \\
\text { (9 dogs) RITC, } 44 \% \text { ( } 44 \text { dogs) reconstruction } \\
\text { - Of those treated with medical management initially, } 40 \% \text { (19 } \\
\text { dogs) then underwent surgical treatment of either RITC or } \\
\text { reconstruction }\end{array}$ \\
\hline Study design: & Retrospective \\
\hline Outcome studied: & $\begin{array}{l}\text { - Subjective owner assessment and re-examination by } \\
\text { attending clinician in some cases, others only phone } \\
\text { interview } \\
\text { - Success defined by full or acceptable function } \geq 1 \text { year post- } \\
\text { treatment as judged by the owner and clinician } \\
\text { - If a dog failed medical management and then had surgery it } \\
\text { was only evaluated in the surgery group }\end{array}$ \\
\hline $\begin{array}{l}\text { Main findings: } \\
\text { (relevant to PICO question): }\end{array}$ & $\begin{array}{l}\text { MSI: follow-up > } 1 \text { year for } 62 \text { dogs, treatment was deemed } \\
\text { successful in } 9 \text { dogs treated with medical management } \\
\text { (69\%), } 4 \text { dogs treated with RITC ( } 80 \%) \text {, and } 38 \text { dogs treated } \\
\text { with reconstruction ( } 86 \% \text {, there were } 44 \text { dogs treated with } \\
\text { surgery, } 1 \text { having bilateral reconstruction) }\end{array}$ \\
\hline
\end{tabular}




\begin{tabular}{|c|c|}
\hline & $\begin{array}{l}\text { - MSI: reconstruction } 3 \text { times more likely to have successful } \\
\text { outcome than medical management ( } p-0.011 \text { ) and } 1.6 \\
\text { times more likely than RITC ( } p=0.44) \text {; RITC } 1.8 \text { times more } \\
\text { likely to be successful than medical management ( } p=0.36) \\
\text { - MSI: surgery may be better than medical management, } \\
\text { however, many patients did well with no surgical } \\
\text { intervention }\end{array}$ \\
\hline Limitations: & $\begin{array}{l}\text { - Retrospective study } \\
\text { - Not all dogs were re-evaluated, therefore the study may be } \\
\text { biased towards those that did not do well } \\
\text { - Unblinded re-evaluation of patients } \\
\text { Dogs not randomly assigned to groups, likely bias in what } \\
\text { was recommended in the first place }\end{array}$ \\
\hline
\end{tabular}

O'Donnell et al. (2017)

\begin{tabular}{|c|c|}
\hline Population: & Canine \\
\hline Sample size: & $\mathrm{n}=39$ dogs with medial shoulder instability (MSI) \\
\hline Intervention details: & $\begin{array}{l}\text { - All dogs underwent arthroscopic evaluation and arthroscopic } \\
\text { assisted extracapsular stabilisation with a prosthetic } \\
\text { ligament } \\
\text { - Multifilament braided strand of ultra-high molecular weight } \\
\text { long chain polyethylene and polyester double looped } \\
\text { through a stainless-steel button and toggle used as } \\
\text { prosthetic ligament } \\
\text { - Lateral or dorsal arthroscopic evaluation } \\
\text { - Guidewire placed from medial aspect of shoulder joint into } \\
\text { joint and visualised arthroscopically as placed with goal of } \\
\text { placement on glenoid rim at the midpoint of the origin of the } \\
\text { medial glenhumeral (MGL) with the lateral exit point in the } \\
\text { supraspinatus fossa just cranial to the spine of the scapula } \\
\text { and just proximal to the neck of the scapula } \\
\text { Second guidewire placed into the joint from the medial } \\
\text { aspect and arthroscopically visualised at the proximal aspect } \\
\text { of the humerus; if the MGL was primarily affected the goal } \\
\text { was placement at the insertion of the MGL, or if } \\
\text { subscapularis tendon (SST) was primarily affected at its } \\
\text { insertion point on the humerus, if both were affected it was } \\
\text { placed midpoint between the two structures or two separate } \\
\text { guidewires were placed, one at each insertion; the angle of } \\
\text { insertion was so that the lateral exit point was on the } \\
\text { caudodistal aspect of the greater tubercle slightly cranial to } \\
\text { the acromial head of the deltoid muscle on the lateral aspect } \\
\text { of the humerus }\end{array}$ \\
\hline
\end{tabular}




\begin{tabular}{|c|c|}
\hline & $\begin{array}{l}\text { - A bone tunnel was drilled from lateral to medial on the } \\
\text { scapula and the suture passed from medial to lateral with } \\
\text { the toggle being pulled through to the lateral aspect } \\
\text { - Dogs placed in hobbles for } \geq 4 \text { weeks at surgeon discretion if } \\
\text { MSl grade < 4; grade } 4 \text { dogs placed in spice splint for } 4-8 \\
\text { weeks followed by hobbles for } 4-8 \text { weeks }\end{array}$ \\
\hline Study design: & Retrospective \\
\hline Outcome studied: & $\begin{array}{l}\text { - Minimum } 6 \text { month follow-up } \\
\text { - MSI graded as grade } 1 \text { (mild MSI) = laxity without gross } \\
\text { tearing of the MGL or SST; grade } 2 \text { (moderate MSI) = partial } \\
\text { tear of the MGL, SST, or both; grade } 3 \text { (severe MSI) = } \\
\text { complete tear of the MGL, SST, or both; and grade } 4 \\
\text { (luxation) = complete displacement of the humeral head in } \\
\text { relation to the glenoid cavity } \\
\text { - Orthopaedic exam, range of motion and subjective } \\
\text { assessment of comfort performed at recheck } \\
\text { - Owner assessment at final follow-up appointment } \\
\text { Outcome defined as: } \\
\text { full function (restoration or maintenance of the dogs } \\
\text { intended level of activities and performance to } \\
\text { preinjury status without medication) } \\
\text { acceptable function (the dogs intended activities and } \\
\text { performance (with or without medication) were } \\
\text { similar to the preinjury status but limited in level or } \\
\text { duration, or equaled the preinjury status but required } \\
\text { medication to achieve) } \\
\text { unacceptable function (all other outcomes) }\end{array}$ \\
\hline $\begin{array}{l}\text { Main findings: } \\
\text { (relevant to PICO question): }\end{array}$ & $\begin{array}{l}\text { - All dogs failed some sort of medical management prior to } \\
\text { surgery; two dogs had undergone previous radiofrequency } \\
\text { induced thermal capsulorrhaphy (RITC) and had clinically } \\
\text { performed poorly following that procedure } \\
\text { - Mean pre-operative abduction angle was } 47.8^{\circ} \text { (range } 37- \\
61^{\circ} \text { ) on affected limb vs. mean } 31.4^{\circ} \text { (range } 15-42^{\circ} \text { ) on } \\
\text { contralateral normal limb } \\
\text { - MSI grade } 1 \text { in } 3 / 39 \text { cases, grade } 2 \text { in } 25 / 39 \text {, grade } 3 \text { in } 7 / 39 \text {, } \\
\text { and grade } 4 \text { in } 4 / 39 \\
\text { - Mean follow-up } 20 \text { months (range } 6-68) \\
\text { - Intra-operatively two cases difficult to seat toggle button, } \\
\text { neither had long-term complications and both regained } \\
\text { normal function } \\
4 / 39 \text { dogs had a major complication; } 2 / 39 \text { had a minor } \\
\text { complication for overall complication rate of } 15 \% \text { (6/39 } \\
\text { dogs) } \\
\text { Of the } 39 \text { dogs treated, } 30 \text { were performance dogs; } 28 / 30 \text { of } \\
\text { these dogs ( } 93 \% \text { ) returned to performance activities } \\
\text { - All dogs were deemed to have a successful outcome with }\end{array}$ \\
\hline
\end{tabular}




\begin{tabular}{|c|c|}
\hline & $\begin{array}{l}\text { 77\% cases (30/39) regaining full function, and } 23 \% \text { having an } \\
\text { acceptable outcome (9/39); } \\
\circ \text { Grade } 1 \text { dogs: } 2 / 3 \text { full function } 1 / 3 \text { acceptable } \\
\circ \text { Grade } 2 \text { dogs: } 22 / 25 \text { full function } 3 / 25 \text { acceptable } \\
\circ \text { Grade } 3 \text { dogs: } 3 / 7 \text { full function } 4 / 7 \text { acceptable } \\
\circ \text { Grade } 4 \text { dogs: } 3 / 4 \text { full function } 1 / 4 \text { acceptable }\end{array}$ \\
\hline Limitations: & $\begin{array}{l}\text { - Retrospective study } \\
\text { - Three surgeons performed the surgery with varying levels of } \\
\text { experience } \\
\text { - Postoperative care varied for cases; } 31 \text { underwent formal } \\
\text { physical therapy } \\
\text { - No objective outcome measures such as objective gait } \\
\text { evaluation, shoulder abduction angle measurement } \\
\text { postoperatively, or joint range of motion performed }\end{array}$ \\
\hline
\end{tabular}

\begin{tabular}{|c|c|}
\hline \multicolumn{2}{|l|}{ O’Neill \& Innes (2004) } \\
\hline Population: & Canine \\
\hline Sample size: & One 3-year-old intact male springer spaniel \\
\hline Intervention details: & $\begin{array}{l}\text { - } 20 \text { months duration left forelimb lameness } \\
\text { - Treated conservatively with nonsteroidal anti-inflammatory } \\
\text { drugs (NSAIDs), improved but recurred, and became } \\
\text { progressive } \\
\text { - Then treated with arthroscopy to evaluate joint and } 40 \mathrm{mg} \\
\text { methylprednisolone } \\
\text { - Minimal improvement so repeated arthroscopy } 6 \text { weeks } \\
\text { later; radiofrequency CAP-Sure wand } 3 \mathrm{~mm} \text { straight from } \\
\text { (ArthroCare), setting 1, held } 1 \mathrm{~mm} \text { from capsule in } \\
\text { craniomedial joint and energy delivered for } 5 \text { seconds; } \\
\text { repeated at intervals moving caudally along joint capsule } \\
\text { - Velpeau sling } 6 \text { weeks }\end{array}$ \\
\hline Study design: & Retrospective case study \\
\hline Outcome studied: & $\begin{array}{l}\text { Subjective assessment of lameness and outcome by veterinarian } \\
\text { based on visual gait analysis and physical exam }\end{array}$ \\
\hline $\begin{array}{l}\text { Main findings: } \\
\text { (relevant to PICO question): }\end{array}$ & $\begin{array}{l}5 \text { months post radiofrequency treatment of dog's gait was improved } \\
\text { - no lameness at a walk, minor discomfort after exercise and with } \\
\text { range of motion of the shoulder }\end{array}$ \\
\hline Limitations: & $\begin{array}{l}\text { - No objective assessment made } \\
\text { - Follow-up was only } 5 \text { months post-treatment }\end{array}$ \\
\hline
\end{tabular}




\begin{tabular}{|c|c|}
\hline Penelas et & \\
\hline Population: & Canine \\
\hline Sample size: & $\mathrm{n}=1 ; 12$-year-old intact female miniature Poodle \\
\hline Intervention details: & $\begin{array}{l}\text { - Description of technique for arthroscopic assisted prosthetic } \\
\text { ligament } \\
\text { - Dorsal recumbency for arthroscopy and procedure with } \\
\text { hanging leg technique } \\
\text { - A } 2 \text { mm SutureTak with Fiberwire } 1 \text { USP (Arthrex Vet } \\
\text { Systems) was placed on the medial aspect of the joint on the } \\
\text { humeral head proximal to the insertion point of the cranial } \\
\text { arm of the medial glenohumeral ligament (MGL) } \\
\text { - An aiming device (Arthrex Vet Systems) was used to drill a } \\
\text { guidewire from lateral to medial through the scapular neck } \\
\text { and then over drilled with a cannulated drill bit; Fiberwire } \\
\text { was passed through this from medial to lateral and tied over } \\
\text { a button via a small incision on the lateral aspect of the } \\
\text { scapula; the suture was tied with joint at standing angle of } \\
110^{\circ} \\
\text { Strict rest for } 6 \text { weeks in hobbles }\end{array}$ \\
\hline Study design: & Case report \\
\hline Outcome studied: & $\begin{array}{l}\text { Owner reported outcome via phone interview at } 6 \text { months } \\
\text { postoperative }\end{array}$ \\
\hline $\begin{array}{l}\text { Main findings: } \\
\text { (relevant to PICO question): }\end{array}$ & $\begin{array}{l}\text { - Pre-operative affected limb abduction angle was } 55^{\circ} \\
\text { compared to contralateral limb } 30^{\circ} \\
\text { - MRI suspected rupture of the } M G L \text { and disruption of the } \\
\text { subscapularis tendon and muscle } \\
\text { - Dog was lame at } 6 \text { week recheck, grade } 1 / 4 \text { compared to } 4 / 4 \\
\text { non-weight bearing at presentation with good range of } \\
\text { motion } \\
\text { - At } 6 \text { months phone interview follow-up the owners reported } \\
\text { no lameness and sent videos confirming this for evaluation }\end{array}$ \\
\hline Limitations: & $\begin{array}{l}\text { - Only one case reported } \\
\text { - No objective outcome measures such as objective gait } \\
\text { analysis, joint range of motion, or validated pain score } \\
\text { performed } \\
\text { - Only phone interview for long-term follow-up, though video } \\
\text { of the dog was available for review }\end{array}$ \\
\hline
\end{tabular}




\begin{tabular}{|c|c|}
\hline Pettitt (2007) & \\
\hline Population: & Canine \\
\hline Sample size: & $\mathrm{n}=$ five clinical cases, 12 cadaveric cases \\
\hline Intervention details: & $\begin{array}{l}\text { - Cadaveric model ( } \mathrm{n}=6 \text { ) used to assess effect of imbricating } \\
\text { the subscapularis muscle tendon of insertion (SSTOI) } \\
\text { - SSTOI: craniomedial approach to the shoulder joint, SSTOI } \\
\text { identified, horizontal mattress suture pattern placed in the } \\
\text { proximal to distal extremities of the tendon of insertion of } \\
\text { the subscapularis muscle with the distal end passing through } \\
\text { the centre of the tendon body using } 2,4 \text {, or } 5 \text { metric } \\
\text { polydioxonones suture (PDS II, Ethicon); routine closure } \\
\text { - Cadaveric model ( } n=6 \text { ) used to assess the effect of } \\
\text { transection on the cranial arm of the medial glenohumeral } \\
\text { ligament and joint capsule followed by imbrication of the } \\
\text { SSTOI on the angle of abduction of the shoulder joint } \\
\text { Clinical cases, } n=5 \\
\text { Four dogs initially treated with arthroscopy only; } \\
\text { intra-articular treatment with } 33 \text { mg/kg } \\
\text { methylprednisolone } n=2 \text {; thermal capsulorrhaphy } n \\
=2 \text { with bipolar radiofrequency (CAP-Sure wand } 3 \\
\text { mm straight, System } 2000 \text { Arthrocare UK) at setting } \\
\text { 2, with wand placed } 1 \text { mm from capsular tissue for } 5 \\
\text { seconds repeated at intervals along the capsule in a } \\
\text { spot welding technique } \\
\text { All four dogs in modified thoracic jacket for } 6 \text { weeks } \\
\text { post-operative; } 5-10 \text { minute leash walks and } \\
\text { hydrotherapy up to } 30 \text { minutes once weekly for } 4 \\
\text { weeks; at this time point second hydrotherapy } \\
\text { session added } \\
\text { SSTOI performed after this in all four dogs at a later } \\
\text { date } \\
\text { SSTOI performed primarily in one dog }\end{array}$ \\
\hline Study design: & Case series \\
\hline Outcome studied: & $\begin{array}{l}\text { - Orthopaedic exam } \\
\text { - Pre-operative and immediate postoperative abduction angle } \\
\text { measured } \\
\text { - } 10 \text { day recheck, } 4 \text { month postoperative recheck and final } \\
\text { exam 7-15 months postoperative (mean } 11.8 \text { months) }\end{array}$ \\
\hline $\begin{array}{l}\text { Main findings: } \\
\text { (relevant to PICO question): }\end{array}$ & $\begin{array}{l}\text { - Pre-operative abduction angle median } 53^{\circ} \text { (range } 50-90^{\circ} \text { ) } \\
\text { improvement, two only slight improvement; subsequently } \\
\text { these all underwent SSTOI } \\
\text { - SSTOI significantly reduced abduction angle; median } 34^{\circ} \\
\text { postoperatively (range } 30-35^{\circ} \text { ) with } p=0.0117 \\
\text { - Lameness fully resolved in three cases and greatly improved } \\
\text { in two cases }\end{array}$ \\
\hline
\end{tabular}




\begin{tabular}{|c|c|}
\hline & $\begin{array}{l}\text { - Improvement seen within } 2 \text { months of surgery } \\
\text { - No recurrence of lameness at mean of } 12.6 \text { months } \\
\text { - } \quad \text { One case that did not do well was later diagnosed with } \\
\text { elbow osteoarthritis } \\
\text { - One case comfortable on exam, but owners reported } \\
\text { intermittent mild lameness following exercise }\end{array}$ \\
\hline Limitations: & $\begin{array}{l}\text { - No comparison to other surgical interventions directly } \\
\text { - No objective gait analysis performed }\end{array}$ \\
\hline
\end{tabular}

\begin{tabular}{|c|c|}
\hline \multicolumn{2}{|l|}{ Pucheau \& Duhautois (2008) } \\
\hline Population: & Canine \\
\hline Sample size: & $\begin{array}{l}\mathrm{n}=76 \text { dogs with shoulder instability (all directions included, } \\
\text { traumatic and non-traumatic included) } \\
\begin{array}{l}\text { - } \mathrm{n}=61 / 76(80 \%) \text { dogs with medial instability } \\
\text { - } \mathrm{n}=14 / 76(19 \%) \text { dogs with lateral instability } \\
\text { - } \mathrm{n}=1 / 76(1 \%) \text { dog with cranial instability }\end{array}\end{array}$ \\
\hline Intervention details: & $\begin{array}{l}\text { - } 4 / 76 \text { dogs treated conservatively with closed reduction and } \\
\text { immobilisation } \\
\text { - } 58 / 76 \text { cases treated with biceps tendon transposition } \\
\text { - } 14 / 76 \text { cases treated with arthrodesis } \\
\text { question) treated surgically with a transposition a } \\
\text { craniomedial approach to the joint was made, and the } \\
\text { transverse humeral ligament was sectioned to allow the } \\
\text { biceps tendon to be withdrawn from intertubercular groove; } \\
\text { the biceps tendon was then transposed to a medial position } \\
\text { behind the lesser tubercle to provide support, and secured } \\
\text { with U shaped staple made from a K wire, implanted to } \\
\text { prevent tendon from being compressed; the joint capsule } \\
\text { was plicated, with the deep pectoral muscle being sutured to } \\
\text { superficial pectoral, the subscapularis to the deep pectoral, } \\
\text { and the superficial pectoral to the acromial part of the } \\
\text { deltoid; postoperatively dogs were placed in a velpeau sling } \\
2 \text { weeks }\end{array}$ \\
\hline Study design: & Retrospective case series \\
\hline Outcome studied: & $\begin{array}{l}\text { Evaluated at least } 4 \text { months postoperatively (mean } 16.5 \\
\text { months) in person physical exam or owner reported } \\
\text { outcome } \\
\text { - Sedated exam to evaluate stability of shoulder at recheck } \\
\text { including abduction angle in some cases } \\
\text { - Functional outcome graded; excellent (not lame), good } \\
\text { (intermittent post-exercise lameness, disappearing following }\end{array}$ \\
\hline
\end{tabular}




\begin{tabular}{|c|c|}
\hline & $\begin{array}{l}\text { the administration of anti-inflammatory drugs), average } \\
\text { (frequent lameness after rest, requiring irregular } \\
\text { administration of non-steroidal anti-inflammatory drugs), } \\
\text { poor (permanent lameness) }\end{array}$ \\
\hline $\begin{array}{r}\text { Main findings: } \\
\text { (relevant to PICO question): }\end{array}$ & $\begin{array}{l}\text { - } 61 / 76(80 \%) \text { had medial instability; average age } 4.6 \text { years } \\
\text { - } 30 / 61 \text { ( } 49 \%) \text { cases of medial instability were deemed } \\
\text { traumatic luxations; of these } 50 \text { were treated with tendon } \\
\text { transposition (the other cases are not reported on here as } \\
\text { they do not relate to the PICO question) } \\
\text { - Good to excellent outcome reported in } 42 / 50 \text { ( } 82 \% \text { ) cases } \\
\text { treated surgically with medial transposition } \\
\text { - For dogs treated with medial transposition abduction angle } \\
\text { was reported on for } 43 \text { cases } \\
\text { o } 29 / 43 \text { ( } 67 \% \text { ) had increased abduction angle pre- } \\
\text { operatively, post-operatively only } 10 / 43 \text { ( } 23 \% \text { ) had an } \\
\text { increased abduction angle } \\
\text { - Four dogs medically managed (not reported if they were } \\
\text { medial or lateral luxations); three had a reported outcome of } \\
\text { 'average', and one excellent (no indication of medial vs. } \\
\text { lateral instability) } \\
\text { Average to poor outcome in eight dogs (number of medial } \\
\text { vs. lateral not indicated); } 5 / 8 \text { ( } 63 \% \text { ) similar degree of } \\
\text { instability as pre-operative }\end{array}$ \\
\hline Limitations: & $\begin{array}{l}\text { - The data presented in this study are difficult to follow, with } \\
\text { some dogs being omitted from some of the data } \\
\text { presentation } \\
\text { - Only } 74 \% \text { of cases seen by veterinarian for recheck, rest } \\
\text { owner reported outcome } \\
\text { - Cases categorised as good to excellent, so maybe most were } \\
\text { good not excellent } \\
\text { - Cases of traumatic luxation mixed in with non-traumatic so } \\
\text { unable to differentiate medial shoulder instability (MSI) } \\
\text { cases from trauma or congenital luxation } \\
\text { - No comparison of other surgical techniques made } \\
\text { - } \text { performective evaluation of gait or shoulder abduction } \\
\text { Only four dogs medically managed }\end{array}$ \\
\hline
\end{tabular}




\begin{tabular}{|c|c|}
\hline \multicolumn{2}{|l|}{ Vasseur et al. (1983) } \\
\hline Population: & Canine \\
\hline Sample size: & $\begin{array}{l}16 \text { research dogs; } 5 \text { groups: } \\
\text { - Group } 1 \text { - lateral control, } \mathrm{n}=3 \\
\text { - Group } 2 \text { - medial control, } \mathrm{n}=3 \\
\text { - Group } 3 \text { - lateral transfer of biceps tendon, } \mathrm{n}=4 \\
\text { - Group } 4 \text { - medial transfer of biceps tendon, } \mathrm{n}=3 \\
\text { - Group } 5 \text { - medial transfer of supraspinatus insertion } \\
\text { (partial), } \mathrm{n}=2 \\
\text { (Numbers are written as is stated in the study) }\end{array}$ \\
\hline Intervention details: & $\begin{array}{l}\text { - Dogs were assigned to } 1 \text { of } 5 \text { groups listed above; lateral or } \\
\text { medial shoulder instability was created } \\
\text { - For medial instability, an open approach was used and the } \\
\text { tendon of the subscapularis tendon, medial joint capsule, } \\
\text { and medial glenohumeral ligament (MGL) were transected } \\
\text { - In control dogs, no closure of these structures was } \\
\text { performed } \\
\text { - For treatment Group } 4 \text { the biceps tendon was freed from the } \\
\text { intertubercular groove and moved into a groove placed } \\
\text { under the lesser tubercle and secured with two small pins } \\
\text { For treatment Group } 5 \text { an osteotome was used to cut the } \\
\text { proximal half to the greater tubercle with a part of the } \\
\text { insertion of the supraspinatus muscle, which was then } \\
\text { moved to a medial location on the lesser tubercle and } \\
\text { secured with a tension band }\end{array}$ \\
\hline Study design: & Prospective, randomised, terminal study \\
\hline Outcome studied: & $\begin{array}{l}\text { - Clinical outcome of subjective lameness assessment prior to } \\
\text { euthanasia } \\
\text { - Development of osteoarthritis was evaluated grossly at } \\
\text { necropsy, as well as radiographically, and via histopathology } \\
\text { of the articular surfaces and subchondral bone }\end{array}$ \\
\hline $\begin{array}{l}\text { Main findings: } \\
\text { (relevant to PICO question): }\end{array}$ & $\begin{array}{l}\text { - Control dogs walked normally within } 2 \text { weeks of surgery, } \\
\text { with no joint abnormalities noted on palpation } \\
\text { - Group 4, and } 5 \text { had prolonged recovery vs. the control } \\
\text { - Groups } 4 \text { and } 5 \text { regained normal limb usage faster than dogs } \\
\text { in Group } 3 \text { and were usually sound by } 4 \text { weeks } \\
\text { - No joints had instability at necropsy; all joints had normal } \\
\text { range of motion at necropsy } \\
\text { - All dogs developed some gross evidence of osteoarthritis } \\
\text { (OA) as well as histopathologic evidence of OA; while all dogs } \\
\text { developed some degree of OA, comparatively Group } 4 \\
\text { reported a higher degree of OA. } \\
\text { - Group } 4 \text { with medial transfer of the biceps showed } \\
\text { stretching of the tendon at necropsy }\end{array}$ \\
\hline
\end{tabular}




\begin{tabular}{|l|l|}
\hline & $\begin{array}{l}\text { - The control group ended up being as stable as the treatment } \\
\text { groups and actually recovered more quickly }\end{array}$ \\
\hline Limitations: & - $\begin{array}{l}\text { This was not true medial shoulder instability, but rather a } \\
\text { manufactured instability that was treated immediately, thus } \\
\text { it does not truly mimic disease }\end{array}$ \\
- No objective evaluations of gait, pain, or range of motion \\
were performed \\
The number of dogs allocated to the groups adds up to 15 \\
and not 16 which is stated in the sample size
\end{tabular}

\section{Appraisal, application and reflection}

Ten studies were reviewed in this knowledge summary. None were prospective clinical studies, and most had very small case numbers, or were case reports. As none were prospective clinical studies, and none had the same treatments, it is very challenging to make any direct comparisons of the data reported and assess outcomes between treatment methods.

Franklin et al. (2013) reported that surgical intervention may be superior to medical management. However, this report was retrospective in nature, and evaluated lateral, medial and multidirectional instability. Furthermore, multiple surgical treatments were used, and many dogs did well with medical management alone. Medial tendon transposition provided a good to excellent functional outcome in $84.5 \%$ of cases reported by Puchea \& Duhautois (2008) however, this retrospective case series included cases of lateral shoulder instability as well as traumatic cases of medial instability, which are different aetiologies than chronic use leading to MSI. O'Neil \& Innes (2004), reported a single case report of a 3 year intact springer spaniel that was treated with RITC for MSI. This case report was one of the first reports in the veterinary literature of using RITC as a treatment for MSI. The dog reportedly did well, but follow up was subjective, and only 5 months post-surgery. Cook et al. (2005) later reported a 93\% improvement in clinical function (79\% excellent) when treating MSI with thermal capsulorrhaphy. The outcomes reported by Cook et al. (2005) are some of the more robust reported given that they performed an objective evaluation of shoulder abduction angles as a component of their assessment of success versus Puchea \& Duhautois (2008) who only subjectively evaluated their cases.

Pettitt et al. (2007) described imbricating the subscapularis tendon for treatment of shoulder instability with good success, which was equal to the outcome reported by Fitch et al. (2001) for placing a prosthetic capsule with suture anchors and/or bone tunnels. None of these had a robust objective evaluation of the outcomes reported.

Thermal capsulorrhaphy appears to have a high rate of success for treating MSI as reported by Cook et al. (2005) with 93\% success, however the reported return to improved function took 12-16 weeks with full function only occurring around 5-6 months postoperatively. This is in comparison to the retrospective report by O'Donnell et al. (2017) who reported a 77\% success rate with placement of a prosthetic ligament, but in a more rapid time frame for return to function with full sport activity (including agility competition and police dog work) occurring on average 16-20 weeks postoperatively. More recently, Penelas et al. (2018), reported a case report of full arthroscopic assisted treatment of MSI with a prosthetic ligament. While, not novel, this is the first published report using this technique. No objective outcome measures were reported, and long term follow-up was based on owner assessment via phone interview at only 6 months postoperatively.

Becker et al. (2015) discussed numerous cases of shoulder related lameness treated medically with shockwave therapy. Only 4 cases in the series were medial shoulder instability cases. Therefore, it is difficult to make 
substantial conclusions regarding the success of treatment. Furthermore, only 3 were available for long term follow-up, and all were still lame, suggesting that shockwave alone may not be a good medical treatment option for MSI.

The 10 studies reviewed in this knowledge summary do not provide a definitive best treatment option for MSI, either medical or surgical. Additional studies that are comparative and prospective in nature will be needed prior to making any definitive assessment of best treatment practice for dogs with MSI.

\section{Methodology Section}

\begin{tabular}{|c|c|}
\hline \multicolumn{2}{|l|}{ Search Strategy } \\
\hline $\begin{array}{r}\text { Databases searched and dates } \\
\text { covered: }\end{array}$ & CAB Abstracts and PubMed 1910 - June 2018 \\
\hline Search terms: & $\begin{array}{l}\text { CAB Abstracts: } \\
\text { 1. dog or dogs or canine or canines or canis or bitch or bitches or } \\
\text { puppy or puppies or pup or pups or exp dogs/ or exp bitches/ or exp } \\
\text { puppies/ or exp canidae/ or exp canis/ } \\
\text { 2. medial shoulder instability or MSI or medial glenohumeral } \\
\text { ligament or (shoulder and (instab* or unstab* or reconst*)) } \\
\text { 3. } 1 \text { and } 2 \\
\text { PubMed: } \\
\text { 1. dog OR dogs OR canine OR canines } \\
\text { 2. medial shoulder instability OR MSI OR medial glenohumeral } \\
\text { ligament } \\
\text { 3. } 1 \text { and } 2\end{array}$ \\
\hline Dates searches performed: & 22/06/2018 (second PubMed Search 25/10/2018) \\
\hline
\end{tabular}

\section{Exclusion / Inclusion Criteria}

\begin{tabular}{|r|r|}
\hline Exclusion: & Non-veterinary related studies; anatomic studies \\
\hline Inclusion: & Veterinary canine studies regarding treatment of MSI \\
\hline
\end{tabular}




\begin{tabular}{|c|c|c|c|c|c|c|c|}
\hline \multicolumn{8}{|c|}{ Search Outcome } \\
\hline Database & $\begin{array}{c}\text { Number } \\
\text { of } \\
\text { results }\end{array}$ & $\begin{array}{l}\text { Excluded: } \\
\text { abstract }\end{array}$ & $\begin{array}{c}\text { Excluded: } \\
\text { anatomic } \\
\text { study/radiology } \\
\text { study/diagnostic } \\
\text { study }\end{array}$ & $\begin{array}{c}\text { Excluded: } \\
\text { treatment of } \\
\text { other shoulder } \\
\text { disease not } \\
\text { MSI }\end{array}$ & $\begin{array}{l}\text { Excluded: } \\
\text { study } \\
\text { regarding } \\
\text { non- } \\
\text { shoulder } \\
\text { veterinary } \\
\text { disease }\end{array}$ & $\begin{array}{l}\text { Excluded: } \\
\text { not } \\
\text { related to } \\
\text { topic at all }\end{array}$ & $\begin{array}{c}\text { Total } \\
\text { relevant } \\
\text { papers }\end{array}$ \\
\hline $\begin{array}{l}\text { CAB } \\
\text { Abstracts }\end{array}$ & 65 & 7 & 21 & 18 & 9 & 2 & 8 \\
\hline PubMed & 52 & 0 & 6 & 1 & 3 & 19 & 2 \\
\hline \multicolumn{7}{|c|}{ Total relevant papers when duplicates removed } & 10 \\
\hline
\end{tabular}

\section{CONFLICT OF INTEREST}

The authors declare no conflict of interest.

\section{REFERENCES}

1. Becker, W., Kowaleski, M.P., McCarthy, R. \& Blake, C.A. 'Extracorporeal shockwave therapy for shoulder lameness in dogs'. Journal of the American Animal Hospital Association. 2015; 51(1): 15-9. DOI: https://doi.org/10.5326/JAAHA-MS-6175

2. Cook, J.L., Tomlinson, J.L., Fox, D.B., Kenter, K. \& Cook, C.R. 'Treatment of Dogs Diagnosed with Medial Shoulder Instability Using Radiofrequency-Induced Thermal Capsulorrhaphy'. Veterinary Surgery. 2005; 34: 469-475. DOI: https://doi.org/10.1111/i.1532-950X.2005.00071.x

3. Fitch, R.B., Breshears, L., Staatz, A. \& Kudnig, S. 'Clinical evaluation of prosthetic medial glenohumeral ligament repair in the dog (ten cases)'. Veterinary and Comparative Orthopaedics and Traumatology. 2001; 14: 222-228. DOI: https://doi.org/10.1055/s-0038-1632702

4. Franklin, S.P., Devitt, C.M., Ogawa, J., Ridge, P. \& Cook, J.L. 'Outcomes Associated With Treatments for Medial, Lateral, and Multidirectional Shoulder Instability in Dogs'. Veterinary Surgery. 2013; 42: 361364. DOI: https://doi.org/10.1111/j.1532-950X.2013.01110.x

5. O'Donnell, E.M., Canapp Jr., S.O., Cook, J.L. \& Pike, F. 'Treatment of medial shoulder joint instability in dogs by extracapsular stabilization with a prosthetic ligament: 39 cases (2008-2013)'. Journal of the American Veterinary Medical Association. 2017; 251(9): 1042-1052.

DOI: https://doi.org/10.2460/javma.251.9.1042

6. O'Neill, T. \& Innes, J.F. 'Treatment of shoulder instability caused by medial glenohumeral ligament rupture with thermal capsulorrhaphy'. Journal of Small Animal Practice. 2004; 45(10): 521-4.

DOI: https://doi.org/10.1111/i.1748-5827.2004.tb00199.x 
7. Penelas, A., Pozzi, A., Stanczyk, E. \& Gutbrod, A. 'Arthroskopisch-assistierte Stabilisation einer medialen Schulterinstabilität bei einem Zergpudel'. Schweizer Archiv fur Tierheilkunde. 2018; 160(9): 533-538. DOI: https://doi.org/10.17236/sat00174

8. Pettitt, R.A., Clements, D.N. \& Guilliard, M.J. 'Stabilisation of medial shoulder instability by imbrication of the subscapularis muscle tendon of insertion'. Journal of Small Animal Practice. 2007; 48: 626-631. DOI: https://doi.org/10.1111/j.1748-5827.2007.00340.x

9. Pucheau, B. \& Duhautois, B. 'Surgical treatment of shoulder instability a retrospective study on 76 cases (1993-2007)'. Veterinary and Comparative Orthopaedics and Traumatology. 2008; 21: 368-374. DOI: https://doi.org/10.3415/VCOT-07-06-0058

10. Vasseur, P.B., Pool, R.R. \& Klein, K. 'Effects of tendon transfer on the canine scapulohumeral joint'. American Journal of Veterinary Research. 1983; 44(5): 811-5. 


\section{EVIIDEFeE

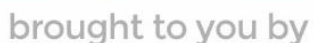 \\ RCVS KNOWLEDGE}

\section{Intellectual Property Rights}

Authors of Knowledge Summaries submitted to RCVS Knowledge for publication will retain copyright in their work, and will be required to grant RCVS Knowledge a non-exclusive license of the rights of copyright in the materials including but not limited to the right to publish, re-

publish, transmit, sell, distribute and otherwise use the materials in all languages and all media throughout the world, and to license or permit others to do so.

\section{Disclaimer}

Knowledge Summaries are a peer-reviewed article type which aims to answer a clinical question based on the best available current evidence. It does not override the responsibility

of the practitioner. Informed decisions should be made by considering such factors as individual clinical expertise and judgement along with patient's circumstances and owners' values. Knowledge Summaries are a resource to help inform and any opinions expressed within the Knowledge Summaries are the author's own and do not necessarily reflect the view of the RCVS Knowledge. Authors are responsible for the accuracy of the content. While the

Editor and Publisher believe that all content herein are in accord with current recommendations and practice at the time of publication, they accept no legal responsibility

for any errors or omissions, and make no warranty, express or implied, with respect to material contained within.

For further information please refer to our Terms of Use.

RCVS Knowledge is the independent charity associated with the Royal College of Veterinary Surgeons (RCVS). Our ambition is to become a global intermediary for evidence based veterinary knowledge by providing access to information

that is of immediate value to practicing veterinary professionals and directly contributes to evidence based clinical decision-making.

https://www.veterinaryevidence.org/

RCVS Knowledge is a registered Charity No. 230886.

Registered as a Company limited by guarantee in England and Wales No. 598443.

Registered Office: Belgravia House, 62-64 Horseferry Road, London SW1P 2AF

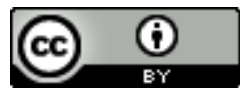

This work is licensed under a Creative Commons Attribution 4.0 International License. 